\title{
Playing with Promethean Fire: Marlowe's Dido, Queen of Carthage and Tamburlaine the Great
}

\section{CHRISTOPHER MURRAY}

UNIVERSITY COLLEGE DUBLIN

\begin{abstract}
Neat Marlowe, bathed in the Thespian springs, Had in him those brave translunary things That the first Poets had; his raptures were All air and fire, which made his verses clear, For that fine madness still he did retain, Which rightly should possess a Poet's brain. ${ }^{1}$
\end{abstract}

I take Drayton's phrase "All air and fire" (above) as cognate with "Promethean": in gifting fire to humanity Prometheus was not only bringing the primary of the four elements - during Marlowe's lifetime forming the constitution of all life - but bringing the arts also to mankind. Marlowe uses the word 'Prometheus' only three times in his works, according to the Concordance, and only one of these is in a play: Dido, Queen of Carthage (3.4.21). ${ }^{2}$ As we shall see below, it makes a difference that the speaker is Dido. In Hero and Leander Marlowe tellingly used the word once. In the first dialogue with Hero, Leander has a rival in Jove, from whom Hebe steals the cup of nectar to give to Mercury which makes Jove more furious "Than for the fire filched by Prometheus / And thrusts him down from heaven" (438-39), suggesting to Christians the fate of Satan. Marlowe prettily extends the myth to Hero's demand, which Leander is determined to satisfy. ${ }^{3}$ At a push, one could identify a second veiled reference in lines 738-40 after Leander has completed his long swim and creeps exhausted and shivering into Hero's bed (from which she has rapidly exited): “And in her lukewarm place Leander lay; / Whose lively heat, like fire from heaven fet, / Would animate gross clay." The image is at once blasphemous and erotic, but it also speaks to new "life": resurrection. It is thus not surprising that Seamus Heaney described Marlowe as an

\footnotetext{
${ }^{1}$ Michael Drayton, "To My Most Dearly Loved Friend Henry Reynolds, Esquire, of Poets and Poesie," in Works, ed. J. William Hebel (Oxford: Blackwell, 1961), 228-29.

${ }^{2}$ Robert J. Fehrenbach, Lea Ann Boone, and Mario A. Di Cesare, eds., A Concordance to the Plays, Poems, and Translations of Christopher Marlowe (Ithaca, NY: Cornell University Press, 1982), 1001.

${ }^{3}$ Christopher Marlowe, Hero and Leander, in The Norton Anthology of English Literature, $5^{\text {th }}$ Edition, Vol. B, ed. Stephen Greenblatt, Katharine Eisaman Maus and George Logan (New York: Norton, 2018). All subsequent quotations from this text refer to this edition.
} 
"original," "a man operating at full tilt, both exhilarated and inflammatory," which is to say Promethean. ${ }^{4}$

Marlowe used the word "fire" far more often than "Prometheus": according to the Concordance a total of seventy-six times in the plays and Hero and Leander and the context is usually Promethean, that is "enlivening." I wish, then, to use "fire" as Denis Donoghue employs it in Thieves of Fire in relation to his reading of Shelley's Prometheus Unbound, Milton's Paradise Lost, Melville's Moby Dick and D. H. Lawrence's fiction passim. "In its simplest version," says Donoghue, "the myth of Prometheus tells a story to account for the origin of human consciousness." "Thus it explores what Christians call "original sin." 6 The gift the Promethean figure brings to human society is actually imagination in its defiant, rebellious mode, subversive to the point where the stolen gift brings to the reader/audience guilt as well as self-consciousness. The Promethean writer projects the Promethean hero who in turn creates the Promethean receptor, the reader or spectator. Of course, the Promethean hero may be a "failure" like the Jew of Malta or a rebel "outsider" like Tamburlaine or Faustus, or a "light-brained king" like Edward II: all loaded terms destined to challenge and transform the audience into empathetic reception. (In The Jew of Malta five of the nine uses of "fire" come from Barabas, always in a context of passion and/or subversion, strangely stamping him as a Promethean.) In discussing Milton's Satan Donoghue sees “fluctuation" or ambiguity in the writer's characterisation which I believe applicable also to Marlowe's style. The sublime invariably invites such ambiguity, and Marlowe's plays exhibit this combination.

In this essay I concentrate on Dido and both Parts of Tamburlaine, where love and destiny are scrutinised in Marlowe's own (unorthodox) tragic terms. In 1 Tamburlaine "fire" is used five times, in 2 Tamburlaine twenty-four times, a discrepancy worth exploring, especially because of the context and speaker in each case, usually Tamburlaine in Promethean fury pursuing ambition, or victory for its own sake. In Dido, where fire symbolises love, it is significant that of the fourteen usages there is a clear division between Aeneas, who has seven before Act 3, and Dido, who has none, while Aeneas has but one after Act 3 while Dido has five from Act 3 to the end, showing the shift in Promethean passion between them.

\footnotetext{
${ }^{4}$ Seamus Heaney, "Extending the Alphabet: On Christopher Marlowe's 'Hero and Leander'," in The Redress of Poetry: Oxford Lectures (London: Faber, 1995), 19.

${ }^{5}$ Denis Donoghue, Thieves of Fire (London: Faber, 1973), 17.

${ }^{6}$ Donoghue, 25.
} 


\section{Dido, Queen of Carthage}

As is well known by theatre historians and scholars of the Elizabethan drama, the 1594 title page of its first publication says The Tragedie of Dido Queene of Carthage was written by Christopher Marlowe and Thomas Nashe and "Played by the Children of her Maiesties Chappell." ${ }^{\prime 7}$ In line with the date of publication, which must be accepted, the inclusion of Nashe as co-author and the identification of the acting company are valuable if controversial details. These two main items, authorship and players, are intertwined. In "Who Wrote Dido, Queen of Carthage?" Ruth Lunney and Hugh Craig have recently addressed the first item, while Martin Wiggins has dealt magisterially with the other in "When Did Marlowe Write Dido, Queen of Carthage?"8 The question marks identify a sharing of serious unease over unsolved problems within the Marlowe canon. The 2020 Lunney and Craig article is in response to Wiggins's 2008 close examination of the authorship issue, and as he finds that Nashe must be included as part author Wiggins focuses on the dates of composition and first production and argues that Dido comes after Tamburlaine "and close to the composition of Doctor Faustus in 1588." "This is an amazing conclusion, from which Lunney and Craig vigorously differ, using digital scholarship in tandem with "stylometric" techniques to disprove Nashe's part (the so-called 'Nasheisms') in the text of Dido, largely by emphasising that in this area "context matters." 10

Judging that the matters under dispute remain so at present, for the purposes of this literary essay I take the liberty of (a) conservatively accepting the standard position that the prose writer Thomas Nashe (1567-1601) had little if anything to contribute to the composition of Dido, Queen of Carthage and, accordingly, that his name is on the title page because as a fellow-Cantabrigian and fellow-author he knew Marlowe and wished to see his play through the press after Marlowe's shocking death in 1593; and (b) that Dido was staged, as the 1594 title page declares, by the Children of the Chapel Royal, but we don't know exactly when. The Children of the Chapel Royal was a prestigious company. In the 1580s the playwrights John Lyly (1554-1606) and George Peele (ca.1557-1596) wrote for it: the former's Campaspe in 1580 or 1581 and the latter's The Arraignment of Paris early in

\footnotetext{
${ }^{7}$ Christopher Marlowe, Dido Queen of Carthage and The Massacre at Paris, ed. H. J. Oliver (London: Methuen, 1968), 2. All subsequent quotations from Dido are keyed to this edition.

${ }^{8}$ See Ruth Lunney and Hugh Craig, "Who Wrote Dido, Queen of Carthage?" Journal of Marlowe Studies 1 (2020): 1-31, and Martin Wiggins, "When Did Marlowe Write Dido, Queen of Carthage?" Review of English Studies 59, no. 241 (2008): 521-41.

${ }^{9}$ Wiggins, "When Did Marlowe Write Dido?" 521.

${ }^{10}$ Lunney and Craig, "Who Wrote Dido?" 14, 9.
} 
1584. ${ }^{11}$ To my knowledge each would have been staged at court. Lyly was taken on as inhouse playwright under the patronage of the Earl of Oxford, and his Endymion, The Man in the Moon, in which Queen Elizabeth is represented by Cynthia, was staged at Greenwich Palace on Candlemas Day (2 February) $1588 .{ }^{12}$ Wiggins himself tells us he believed before publication of his current article that Lyly's troupe "almost certainly" performed Dido as Marlowe's "first play," dramatically adding in the later article, "Both these opinions I now recant." ${ }^{13}$ Recantation is not always a good move. Marlowe's Dido was certainly privileged to have been slotted in somewhere between 1584 and 1588 .

All these "child" plays had classical roots, but only Marlowe's was in blank verse, which must have made an impression with enlightened teachers and audiences in the 1580s. Love was usually the theme and it seems the young players could carry it off quite well within the genre of comedy-taken-seriously, that is to say presented in some measure realistically, although making use of Tudor staging of the kind Sir Philip Sidney mocked, "where you shall have Asia of the one side, and Afric of the other, and so many other underkingdoms, that the player, when he cometh in, must ever begin with telling where he is, or else the tale will not be conceived?"14 Academic mockery of popular forms did not succeed in eliminating them. Even the picky Ben Jonson was to continue the use of stage booths, as Bartholomew Fair (1614) illustrates. Clearly, Marlowe was no snob in the area of the classical unities and went with the instincts of his chief actor Edward Alleyn and his producer the redoubtable Philip Henslowe, owner of the Theatre, the Rose and (later) the Fortune. It happened, in addition, that this partly medieval form of poly-scenic staging of the $1580 \mathrm{~s}$, using portable "mansions" or structures representing a house, a cave, a town in juxtaposition or simply removable as required, found in Dido, sufficed at court as well as in the public theatres, as A. M. Nagler has shown. ${ }^{15}$ We are not far into Marlowe's play when we see how inescapable was the stage dialogue Sidney complained of. Aeneas asks on his first entry, "Where am I now? These should be Carthage walls" (2.1.1). The line demonstrates that Marlowe understood better than Sidney the economy underlying stage production.

Nevertheless, Marlowe's play was classical, his source being the Latin poet Virgil, whose Aeneid tells the story of Dido and Aeneas in full. But the Aeneid is an epic culminating

\footnotetext{
${ }^{11}$ I take these details from the title pages of the first editions of Campaspe and The Arraignment in 1584.

${ }^{12}$ C. F. Tucker Brooke and Nathaniel Burton Paradise, eds., English Drama 1580-1642 (Boston: Heath, 1933), 40 .

${ }^{13}$ Wiggins, "When Did Marlowe Write Dido?", 533n48.

${ }^{14}$ Sir Philip Sidney, A Defence of Poetry, ed. Jan Van Dorsten (Oxford: Oxford University Press, 1973 ), 65.

${ }^{15}$ A. M. Nagler, Shakespeare's Stage (New Haven: Yale University Press, 1958), 38-46.
} 
in the Trojan Aeneas's establishing himself militarily in Italy and positioning himself to found Rome and its future glory as celebrated by Virgil's patron the emperor Augustus. Yet Marlowe's Dido is a tragedy firmly focused on the story of Aeneas's love and betrayal of the woman he meets when he reaches Libya en route. Indeed by giving the play the title he did, with Dido's name having precedence, Marlowe was declaring his critique of Virgil's propagandist epic. Dido was to be the hero, Aeneas the weaker vessel, as is now commonly accepted. Actually, as Andrew Duxfield has pointed out, Marlowe's dramatisation of the love story is more complex than a mere favouring of Dido: characterisation and situation are rendered ambivalent, as in Marlowe's other plays which "tend to problematize rather than endorse" politics and feeling. ${ }^{16}$ The Promethean factor helps to illuminate this point.

Francis Bacon (1561-1626), himself a Cambridge man, took an interest which may cast some light on what Marlowe was doing. Under the heading "Prometheus or the State of Man" Bacon teased out various moral meanings in the "parable" of Prometheus, mentioning "the races with burning torches instituted in honour of Prometheus, [. . .] that is, of Human Nature." Prometheus equals what it means to be human. Bacon went on to stress the "correspondency" to be found in the myth with "the mysteries of the Christian faith." He continues: "The voyage of Hercules especially, sailing in a pitcher to set Prometheus free, seems to present an image of God the Word [Christ] hastening in the frail vessel of the flesh to redeem the human race," but Bacon refrains from further speculation "lest peradventure I bring strange fire to the altar of the Lord." ${ }^{17}$ Here Bacon is patently indulging in medieval anagogy, location of "a higher spiritual meaning behind the literal meaning of a text." ${ }^{18} \mathrm{I}$ should say that this mode of thinking is exactly what Marlowe was opposing. All of his work goes against the Christian grain and the traditional love of allegory. Even Virgil's Aeneid was then read as didactic. Bacon had an empirical mind, and yet to him the Bible was a sacred text to be carefully decoded. From what we know of Marlowe, fortified by the testimony of his accusers in the early 1590s, it is clear he was a free thinker. For him the classics were of more significance than the Bible, even though the Bible is a text Faustus was familiar with and interpreted his own way (which is heresy). ${ }^{19}$ If for Bacon Prometheus was a forerunner of Christ, for Marlowe he was a rebel against orthodoxy and divine rule. As we shall see below,

\footnotetext{
${ }^{16}$ Andrew Duxfield, Christopher Marlowe and the Failure to Unify (Farnham: Ashgate, 2015), 37.

${ }^{17}$ Francis Bacon, "The Wisdom of the Ancients," in The Essays, ed. John Pitcher (Harmondsworth: Penguin, 1985), Appendix 3, 275-76.

${ }^{18}$ Chris Baldick, The Concise Oxford Dictionary of Literary Terms (Oxford: Oxford University Press, 1991$), 9$.

${ }^{19}$ See Christopher Marlowe and his Collaborators and Revisers, Doctor Faustus A-and B-texts (1604, 1616), ed. David Bevington and Eric Rasmussen (Manchester: Manchester University Press, 1993), 16-17.
} 
when Marlowe wrote Tamburlaine, this heterodoxy powered his characterisation, form and language, amounting to an attack both on contemporary notions of allegory (as in Spenser's Faerie Queene) and of dramatic theory (as in Sidney's Defence of Poetry and Renaissance commentary on Aristotle's Poetics).

In Hero and Leander Marlowe used the line Shakespeare was later to steal, "Who ever loved, that loved not at first sight?" (176; cf. As You Like It, 3.5.82). And so it is in Dido, Queen of Carthage with a little help from Venus and her son Cupid. Two scenes will illustrate. They parallel each other with a symmetry Marlowe the craftsman preferred. At the centre of the play, 3.4, Aeneas and Dido take shelter in a cave from a heavy storm. It is a pastoral moment of awkward intimacy. They have left the hunting party and enter separately or "at several times" only to encounter each other as it were by chance; the setting would be one of those "houses" or tents left on stage throughout the production, with an opening at either side. Aeneas says it is like the meeting between Venus and Mars, to which Dido quips "Why, that was in a net, where we are loose; / And yet I am not free-O would I were!" (3.4.4-5). Then she confesses she is in love with someone, that "Prometheus hath put on Cupid's shape, / And I must perish in his burning arms. / Aeneas, O Aeneas, quench these flames!" (3.4.20-22). The scene plays out and they become lovers, a love that "will end in her destruction in flames that are more than figurative." ${ }^{20}$ Because of his historical and theological baggage it is Aeneas who is "playing with fire" here but Dido who must pay the price. While he temporarily falls guilty of default from divinely appointed duty it is Dido who, because she risks everything for love, will prove the true Promethean: the bringer of consciousness, not, as in Virgil's version of the love story, of the political destiny that the gods enforce through Aeneas's obedience but of existential autonomy through defiance of their moral authority. Dido remains steadfast to her commitment to love, while Aeneas reneges. Thus Dido takes over possession of imagery of fire after Act 3.

In this context the final scene, taking up all of Act 5, is cathartic. It is more powerful than Virgil's narrative, with its main focus on Aeneas. There is a line in Virgil, delivered by Mercury in Book 4 degrading Dido in a sweeping generalisation: "Woman's a thing / that's always changing." ${ }^{21}$ In the Latin, Virgil makes femina a neutral noun, as indicated by the adjectives varium and mutabile used in agreement. She becomes an "it." Disagreeing,

\footnotetext{
${ }^{20}$ Douglas Cole, Suffering and Evil in the Plays of Christopher Marlowe (Princeton: Princeton University Press, 1962), 83.

${ }^{21}$ Virgil, The Aeneid, trans. Robert Fagles (London: Penguin, 2006), p.147. Subsequent quotations from the Aeneid are from Fagles's translation, to which page numbers refer.
} 
Marlowe conspicuously drops this line. In Dido as in most of his plays he does not depict women as fickle, but on the contrary as fatally loyal. (Queen Isabella in Edward II is perhaps the exception.) Dido, then, is not a changeable "thing"; she is a woman who is dumped through official, divine disdain.

Before examining Act 5 it is necessary to address the gender issue raised by this play. Sara Munson Deats explains its significance: “Dido's passion remains the galvanizing force, with Aeneas's affection only a flickering reaction to her burning desire." 22 Deats sees the characterisation as androgynous. That this is Marlowe's plan is clear from the opening scene, or Prologue to the play, wherein Jove makes a fool of himself as an older man courting the pretty boy Ganymede, and presenting him with the jewels Juno wore on her wedding day. Yet Jove - who was to punish Prometheus for his philanthropy — is the supposed authority figure in this tragedy, while Juno and Venus are actually more proactive. Through their and Cupid's agency, gender roles are interfered with and romantic "true love" rendered problematic. It can be said, accordingly, that Marlowe subverts decorum and submerges both Dido and Aeneas in moral incoherence. This is the contemporary reading: "Errant eros runs amok." 23 The comic prologue in Dido signals Marlowe's subversive dramatic impulse, which is what "playing with fire" in this context means. As Duxfield argues, authority is ambiguous in Dido, where the gods in charge "deny the audience a stable moral framework on which to build their interpretation of the play." 24 Thus Marlowe's representation carries with it a cool, sophisticated irony.

Up to Act 5 Dido is totally immersed in her passion for Aeneas, believing that he too put love before all else. She is not aware, as the audience is, that Aeneas is under the sway of the gods. Mercury enters at the start of Act 5 to break up Aeneas's plans for constructing Carthage: "Why, cousin, stand you building cities here / And beautifying the empire of this Queen / While Italy is clean out of thy mind?" (5.1.27-29). The words "why," "cities" in the plural, "beautifying" and "Queen" (without a name) are all calculated to diminish and trivialise Aeneas's love. This speech, which goes on for fifteen lines, is a schoolmaster's rebuke to a delinquent boy. Even if Mercury was also played by a boy he could presumably parody a teacher's style; the boy playing Aeneas would know precisely what his role should be when Mercury exits in anger, threatening Aeneas with 'the wrath of frowning Jove'

\footnotetext{
${ }^{22}$ Sara Munson Deats, “'Errant Eros': Transgressions of Sex, Gender, and Desire in Dido, Queene of Carthage," in Christopher Marlowe, ed. Robert A. Logan (Farnham: Ashgate, 2011), 93.

23 Deats, "Errant Eros," 101.

${ }^{24}$ Andrew Duxfield, Christopher Marlowe and the Failure to Unify, 22.
} 
(5.1.54), as it were the headmaster. At this point Marlowe creates a brief scene not in Virgil. Iarbas, the Moroccan king whom Dido dismisses as a wooer in Act 3 but who still stalks her, enters to find Aeneas downhearted and - out of self-interest—needing help to get away from Carthage; Iarbas assures him of assistance. As the two men exit to get the ships ready the relieved Aeneas declares: "Now will I haste unto Lavinian shore [Italy] / And raise a new foundation to old Troy" and so on (5.1.78-9). Dido enters, asking awkward questions, mainly why the men are going on board ship: "Pardon me though I ask; love makes me ask" (90). When Aeneas says farewell she bursts into anger: "Is this the mends for Dido's love? / Do Trojans use their lovers thus?" (105-6). Aeneas would probably prefer a headmaster's rebuke. The word "farewell” dominates the dialogue, as Dido's echoing of Aeneas's language signifies: “'Let me go'; 'farewell'; 'I must from hence': / These words are poison to poor Dido's soul. / O speak like my Aeneas, like my love!" (110-12). When he tries to put the blame on the gods she comes back with the devastating put-down:

The Gods? What Gods be those that seek my death?

Wherein have I offended Jupiter

That he should take Aeneas from mine arms?

O no, the Gods weigh not what lovers do:

It is Aeneas calls Aeneas hence; (5.1.128-32)

The vacillating, deceitful Aeneas is exposed. Promethean Dido has found him out, and will play him off the stage. As Deats has it: "Although Aeneas shares with Dido the top billing as coprotagonist [sic], he is primarily a passive object rather than an active agent in the power struggle, thus totally reversing the gender expectations of the early modern period." 25

In the exchange that follows, Dido points out the price she has already paid for choosing him although "all the world calls me a second Helen, / For being entangled by a stranger's looks" (5.1.144-5). But Aeneas remains cold: "If words might move me, I were overcome" (154). That's all he has left to say: words are insignificant, deeds are the only language of real worth. (In Tamburlaine, Marlowe showed that words and action can be unified if the hero possesses "real worth.") Aeneas's dismissal of language is enough to launch Dido into a barrage of insults before he creeps off, following her final appeal:

If thou wilt stay,

Leap in mine arms: mine arms are open wide.

If not, turn from me, and I'll turn from thee;

For though thou hast the heart to say farewell, I have not power to stay thee (179-83).

${ }^{25}$ Deats, "Errant Eros," 120. 
She cannot believe it when he then goes. She feels certain he will turn back (as Antony was to do in Shakespeare's reworking of this scene for his Antony and Cleopatra (staged 1606-7). But Fate here writes the script and pius Aeneas is not for turning. Dido's recognition scene is played out. Anna enters to ask "What means my sister thus to rave and cry?" (193), so we know that the boy actor had to deliver Dido's preceding ten lines hoping Aeneas will change his mind. She now sends Anna to the ship to request him "gently" to return. Anna comes back with the news of Aeneas's refusal to speak to her as he, "whose heart of adamant or flint / My tears nor plaints could [not] mollify a whit' (234-45), sailed off in haste.

Marlowe's denouement is much as Virgil composed it, but without Virgil's religious content, where Juno, “filled with pity / for Dido’s agonizing death,” speeds down from Olympus "to release her spirit." ${ }^{26}$ Marlowe is more concise and more dramatic. In the earlier love scene, as noted above, Dido had exclaimed: "Prometheus hath put on Cupid's shape, / And I must perish in his burning arms" (3.4.20-21). Her consciousness now works on the audience to endorse this experience. Rhetoric yields to realism as in a neat little passage (not in Virgil) Dido gets Iarbas to help her make a pyre; then, dismissing him, she prepares herself for death:

Now, Dido, with these relics burn thyself, And make Aeneas famous through the world

For perjury and slaughter of a queen. (5.1.292-94)

The enjambment of that second line is revelatory of Marlowe's skill: to be "famous" instead of "infamous" for "perjury" and "slaughter" is rendered brutally cynical as the reader rushes past "the world" without a comma to find only mockery of a deputed hero. Visual emblems are also there on stage to back her rhetoric. With her are the sword Aeneas drew in the "darksome" cave by which he swore to be true, and the Phoenecian garment she gave him when he arrived in rags, together with "these letters, lines, and perjur'd papers" (a neat prosopopeia), all becoming images of betrayal through the force of imagination. All "shall burn to cinders in this precious flame" with her (295-301). Aeneas is being deleted. This is her sacrifice, her Promethean gift to the future Hannibal that he may arise from her ashes "to revenge this treason to a queen" (306-7). Marlowe's Dido can transgressively upend the word "treason" to give her moral victory. Virgil's Dido, in contrast, had cried out, "I shall die unavenged, but die I will So_- / so_-I rejoice to make my way among the shades" (150), submitting to Aeneas's and the gods' moral universe.

\footnotetext{
${ }^{26}$ Virgil, The Aeneid, trans. Robert Fagles (London: Penguin, 2006), 151. Subsequent quotations from the Aeneid are from Fagles's translation, to which page numbers refer.
} 
The poet Virgil could not resist a sequel to his Dido's final line. In Book 6 of the Aeneid, set in the underworld, Dido appears again among those spirits in the Fields of Mourning where "Not even in death do their torments leave them, ever." As Aeneas pauses beside her he recognises her, "a dim, misty figure," and speaks to her: "I heard that you were dead." He weeps to think that he was to blame and swears "by the stars, by the Powers on high, whatever / faith one swears by here in the depths of earth, / I left your shores, my Queen, against my will" (197). That possessive "my Queen" is unforgivable. It is there too in Seamus Heaney's more poetic 2016 version, but Heaney introduces instability in the line Fagles renders mildly as "whatever / faith one swears by here" by rendering it: "by the powers / Above and by any truth there may be under earth." ${ }^{27}$ Marlowe would surely have endorsed "any truth there may be," I believe, because in choosing not to follow up Dido in the afterlife he silently denied that afterlife credence and went for tragic finality. Within Marlowe's text Dido "speaks with the voice of desire that would become the trademark of Marlowe's tragic heroes" 28 because for Marlowe Promethean fire is equated with uncontrollable passion subverting conventional decorum. That fire is sublime: destructive while it is awesome, and vice versa.

\section{Tamburlaine the Promethean}

The prologue to Part 1 of Tamburlaine provides a bridge between Dido and the new play. The territory on the other side of that bridge, however, is entirely different: male-oriented, Romantic, and in-your-face. The eight lines of the prologue, probably the shortest in theatre history, seek to clear a space for a style and form of play not yet seen on the English stage. The tone is lofty, even arrogant, dismissive of the common use of comedy dominating so much of early modern English drama. Marlowe was not going to bend to the demands of merely popular theatre. Instead, allying with the actor Edward Alleyn, "We'll lead you to the stately tent of War" to hear "the Scythian Tamburlaine / Threat'ning the world with high astounding terms" while he scourged royalty "with his conquering sword." Action man had come to town. The final two lines of this prologue-cum-manifesto send out an imperious challenge to the audience: “View but [Tamburlaine's] picture in this tragic glass, / And then applaud his fortunes as you please." ${ }^{29}$ This is to claim tragic status for his hero and at the

\footnotetext{
${ }^{27}$ Virgil, Aeneid Book VI, trans. Seamus Heaney (London: Faber, 2016), 26.

${ }^{28}$ David Riggs, The World of Christopher Marlowe (London: Faber, 2004), 125.

${ }^{29}$ Christopher Marlowe, Doctor Faustus and Other Plays, ed. David Bevington and Eric Rasmussen (Oxford: Oxford University Press, 1995), 3, italics added. All quotations from Tamburlaine the Great, Part 1 and Part 2, are from this edition.
} 
same time a documentary (instructive) value for the play. But to hear and view as instructed make the audience complicit, although the final phrase conveys cool indifference on this point.

At one level Tamburlaine Part 1 embodies a rags-to-riches narrative, since the protagonist is a poor shepherd who thrusts himself into competition with his betters as ambitious warrior and splendid blower of his own trumpet and is successful. Against all the odds he becomes emperor of the Eastern world. This is then, a Renaissance hero to be rejoiced in, since, being in the main an enemy of Turkish and Mohammedan powers, he holds no threat to the English imagination but may be seen as a "mirror" (or "glass," as the Prologue prefers) for the formation of a new national identity. For this reason the play was an outstanding success and in the year of the Spanish Armada of 1588 spawned a sequel in Part 2. On another level Tamburlaine Part 1 throws down the gauntlet to the critical theorists of drama at this time, such as Sir Philip Sidney, by breaking the rules whereby a hero should be a good man with a character flaw which will undo him as a warning against pride allied to ambition. So determined was Marlowe to defy classical rules and Renaissance decorum that he pushed his hero well beyond all conventional artistic boundaries into Promethean daring. In the following century the poet John Milton would create a similar rebel in his Satan, the ambivalent hero of Paradise Lost (1667), whose rebellion against God mirrors that of Prometheus against Zeus. "Prometheus is self-conscious, conscious of himself as a hero, and he is conscious of the line of force which joins him to Zeus. [. . .] He needs Zeus, if for no other reason than that he needs a force at least equal and opposite and preferably greater than himself." 30

This argument works for Milton's Satan and it also works for Tamburlaine, as it speaks to the issue raised by Duxfield regarding Tamburlaine's shifting between the divinities of Jove, God, Mahomet and no god at all as rivals; Duxfield sees this uncertainty as "characteristic of a protagonist that is racked with spiritual confusion. [... ] This indecision undermines Tamburlaine's project of unilateral self-fashioning, since he doubts the very gods on whom he models himself." 31 What Marlowe created, however, was a new mythic figure, amoral and larger than life. After the unheroic Aeneas, Marlowe apparently needed to restore manliness to the English stage, having diminished it in his portrait of Aeneas as anti-hero.

We know that Marlowe sourced his hero in the real Mongolian emperor Timur (13361406), although he turns him into a Renaissance adventurer. I should like to suggest another

\footnotetext{
${ }^{30}$ Donoghue, Thieves of Fire, 53.

${ }^{31}$ Duxfield, Christopher Marlowe and the Failure to Unify, 53.
} 
inspiration, namely the Roman poet Horace. As a Cambridge scholar Marlowe would have been as familiar with Horace as he was with Virgil and Ovid. In Odes 1.3, which nowadays is entitled "To Vergil setting out for Greece," having made a prayer to the gods for Virgil's safe journey, Horace moves on to emphasise the necessity of bravery, given the natural dangers. ${ }^{32}$ But as he marvels at the disregard for death in those travellers who first dared venture forth on the sea, Horace sees this as somehow "impious" and even a crime (nefas), deriving from Prometheus's stealing of fire in defiance of Jupiter:

The human species, audacious enough to endure anything, plunges into forbidden sacrilege. The audacious son of Iapetus [i.e. Prometheus] by an act of criminal deception brought fire to the nations. After the theft of fire from its heavenly home, a wasting disease and an unprecedented troop of fevers fell upon the earth, and the doom of distant death, which up to then was slow in coming, quickened its step. (Odes, p.31)

It is my contention that Marlowe took up the challenge inherent in Horace's intertwining of danger, blasphemy and sin or crime when he imagined an amoral hero indifferent to all three consequences of taking action contrary to divine will. If "Oak and three layers of brass [aes triplex, line 9] were wrapped round the heart of that man who first entrusted a fragile craft to the savage sea" (Odes, 29), much more did Tamburlaine, the disenfranchised shepherd, display "audacity" in crossing barrier after barrier to achieve his dream of an earthly crown against the highest odds? Marlowe saw the seed of a new style of Elizabethan play in this sentiment, where indifference to the moral implications of "impiety" is his hero's boast over and over again. Horace cites Daedalus and Hercules among those foolhardy enough to set out to prove that "nothing is too steep for mortals," but adds: "In our folly we aspire to the sky itself, and by our crimes we do not allow Jove to lay aside his bolts of wrath" (Odes, 31, italics added). On this ambivalent note the poem ends. If we look further into Horace we see similar references. "They say that when Prometheus was compelled to add an element cut from every animal to our primordial clay, he also put into the human heart the violence of a raging lion" (Odes, 1.16, 57). In the playful poem "A narrow escape from death" (Odes, 2.13), he wittily records how a huge tree almost finished him off: "Whoever it was that planted you in the first place did so on an evil day, and with an unholy hand he raised you, Tree, to bring harm to his descendants and disgrace to the district" (Odes, 121). He sees a planter whose gift was also evil. But in elaborating the scale of that evil Horace imagines his death "and the kingdom of dusky Proserpine" where music and poetry are

\footnotetext{
${ }^{32}$ Horace, Odes and Epodes, Loeb Classical Library, ed. and trans. Niall Ross (Cambridge, MA: Harvard University Press, 2004), 28-31. Quotations are from this edition, to which Odes plus page numbers refer.
} 
allowed to the delight of all present: "Why, even Prometheus and Pelops's father are beguiled of their pain by the pleasant sound, and Orion has no interest in hunting lions or timid lynxes" (123). Here the poem ends; again, the ambivalence of good and evil intertwined is the topic. In "The vanity of riches" (Odes 2.18), in parable fashion Horace upbraids a rich man for continuing to plan fresh improvements to his magnificent property to the detriment of neighbours. "Yet no hall awaits its rich owner more surely than the inevitable terminus of grasping Orcus [death, god of the underworld]" whose attendant [Mercury] "could not be bribed with gold to untie Prometheus for all his cunning” (Odes, 135). This reference is crucial to Tamburlaine's belated consciousness of death (2 Tamburlaine, 5.3.119, 248). In Epode 17, also, where Prometheus is registered among the suffering dead, the point is firmly made that the gifted man, the benefactor of mankind, must in the end enter Hades. Thus, if inspired by Horace to model his Tamburlaine on Prometheus Marlowe at first decided to blot out the consequences of death and the hereafter, and in Part 2 needed Tamburlaine finally to transcend these. We have the contemporary reference from Robert Greene, "daring God out of heaven with that Atheist Tamburlan," in evidence of Marlowe's disbelief. ${ }^{33}$ Moreover, in "A narrow escape from death," with its mention of sweet music in Hades, Horace hands Marlowe his cue for Tamburlaine's extraordinary lines, "What is beauty, saith my sufferings, then?"; this leads on to the swerve away from "sufferings" and ends in the celebration of vir, the man of Renaissance virtú, the epitome of "glory" and "true nobility" (1 Tamburlaine 5.1.160-90). My point here is that Marlowe as artist drew on Horace to provide him with a basis for his quite revolutionary dramaturgy but went beyond Horace in denying nemesis. The Promethean hero is sublime rather than morally good. To begin with "the Scourge of God" label, used on the title page of the first known edition, it may be said to beg the question of Tamburlaine's goodness. ${ }^{34}$ In Aristotle's account of tragedy in the Poetics, he insists that the hero should be a good man with some tragic flaw (hamartia). ${ }^{35}$ Moving away from this concept, Marlowe re-created for the Elizabethan age what Eugene Waith dubbed the Herculean hero:

Hercules, as he appears in Sophocles, Euripides, and above all Seneca, is revitalized in Tamburlaine. No one of the older plays was used as a model, but Hercules was often in Marlowe's mind as he wrote. [...] It is finally less important whether Marlowe was deliberately fashioning a Herculean hero than to remember that the

\footnotetext{
${ }^{33}$ John Russell Brown, ed., Tamburlaine the Great, Edward the Second and The Jew of Malta: A Casebook (London: Macmillan, 1982), 1-2.

${ }^{34}$ Brooke and Paradise, English Drama 1580-1642, 137.

${ }^{35}$ Stephen Halliwell, The Poetics of Aristotle: Translation and Commentary (Chapel Hill: University of North Carolina Press, and London: Duckworth, 1987), 44.
} 
traditional depictions of Hercules, especially those from Rome and Renaissance Italy, were thoroughly familiar to him. ${ }^{36}$

It is important also to bear in mind here that Hercules was a sidekick of Prometheus and helped him to pass on fire to humanity. The most significant thing about Tamburlaine is his energy, the inner drive he possesses and that possesses him to cast aside his peasant identity, his humble status, and make himself into a mighty warrior: this is the self-fashioning of which we have heard a great deal, possibly too much. ${ }^{37}$

As introduced, however, Tamburlaine is no blank slate but already inherently a figure of some stature, mentally as well as physically. The contrast with the weakly king Mycetes early on shows this nature immediately, as has often been pointed out. Tamburlaine is a powerful speaker as well as a powerful fighter, whereas King Mycetes's silliness is exposed as much in his inability to frame a strong sentence as it is in his cowardice. Tamburlaine is a licensed boaster:

I hold the Fates bound fast in iron chains And with my hand turn Fortune's wheel about, And sooner shall the sun fall from his sphere

Than Tamburlaine be slain or overcome (1 Tamburlaine, 1.2.174-77).

His role from here on is to prove this boast. Like the greatest boxer of the twentieth century, Muhammad Ali, whose battle-cry was "I am the greatest" and who went on to prove this by becoming three times world champion, Tamburlaine could deliver on his boasts and win many titles. We must, however, bear in mind the difference between art and reality here.

Marlowe subversively holds up for admiration the portrait or "mirror" of a hero whose creed is bloodshed, "Wherein as in a mirror may be seen / His honour, that consists in shedding blood" (1 Tamburlaine, 5.1.474-76). It is a horrific image, nothing to do with sport. The essayist Michel de Montaigne (1553-92) asked: 'who does not picture Tamburlaine with arched brows, open nostrils, a grim visage, and a prodigious stature, in accordance with the picture that the imagination has conceived of him from the report of his fame?"38 On stagein mimesis - Tamburlaine became the very model of an early modern antihero, to the disgust of such arbiters as Ben Jonson. ${ }^{39}$ On stage Tamburlaine did not fight for king and country but

\footnotetext{
${ }^{36}$ Eugene M. Waith, The Herculean Hero in Marlowe, Chapman, Shakespeare and Dryden (New York: Columbia University Press and London: Chatto and Windus, 1962), 63.

${ }^{37}$ Stephen Greenblatt, Renaissance Self-Fashioning: From More to Shakespeare (Chicago: University of Chicago Press, 1980; new edn. 2005). There is now a book on this book: Liam Haydon, Stephen Greenblatt's Renaissance Self-Fashioning (London: Macat, 2018).

${ }^{38}$ Michel de Montaigne, "On Repentance," in Essays, trans. J. M. Cohen (Harmondsworth: Penguin, 1958), Book 3, chapter 2, 241.

${ }^{39}$ Brown, A Casebook, 27.
} 
for histrionic effect: to become a king, and then move on to become a greater and greater king, linguistically conjuring up victories. He calls the process "the sweet fruition of an earthly crown" (1 Tamburlaine, 2.7.29), and his hyperbole is calculated blasphemy. To Elizabethan ears, an "earthly" crown was not what people were born to pursue but a heavenly one, as St Paul advocated (1 Cor. 9: 25-26). Marlowe would have been well aware of this doctrine, but is very forceful in blasting it away without apology. Tamburlaine does not voice his ambition casually. To him the earthly crown is "the ripest fruit of all, / That perfect bliss and sole felicity' (27-28, italics added). He has already coached his won-over men to believe this. Theridimas, "Won with thy words [as is the audience] and conquered by thy looks," soon parrots Tamburlaine's gospel: "A god is not so glorious as a king," a pronouncement which upends Christian doctrine (1 Tamburlaine, 1.2.228, 2.5.57). But it is from his nonChristian opposition that criticism of such blasphemy appears, ushering in imagery of hell and damnation as from a higher order. Thus Cosroe, King of Fez, asks:

What means this devilish shepherd to aspire

With such a giantly presumption,

To cast up hills against the face of heaven

And dare the force of angry Jupiter? (1 Tamburlaine, 2.6.1-4)

Cosroe vows to send this "monstrous slave" to hell, "Where flames shall ever feed upon his soul" (7-8). In condemning him Cosroe actually talks up Tamburlaine's Promethean qualities, referring to "That fiery thirster after sovereignty" whom he will burn "in the fury of that flame / That none can quench but blood and empery" (31-33, italics added). Marlowe gets away with Tamburlaine's disregard of Christian values just because it is English enemies who voice condemnation, whom the audience would, of course, scoff at. ${ }^{40}$ When Tamburlaine defeats Cosroe he annihilates his curse also. Coolly he asks, "What better precedent than mighty Jove?” (1 Tamburlaine, 2.7.17).

Ultimately Tamburlaine sees himself as "The scourge of God and terror of the world" (2 Tamburlaine, 4.1.153). This is unconvincing if meant to define his agency, as in "To scourge the pride of such as heaven abhors" (2 Tamburlaine, 4.1.148). Tamburlaine actually wants it both ways, to be a rebel and yet some kind of defender. Exactly what kind of defender is left to the audience to determine. But there is no sign in the text that, like Hamlet in the scene with his mother (3.4.162-4), Tamburlaine is being punished as "the scourge and

\footnotetext{
${ }^{40}$ Roger Sales, Christopher Marlowe (Basingstoke: Macmillan, 1991), 51-83. Interestingly, Sales shows how Marlowe used the Turks and Scythians to "demonise" the Irish Roman Catholic peasantry (59). No doubt, this made Tamburlaine's violence palatable to Marlowe's audience.
} 
minister" of "heaven." ${ }^{41}$ On the contrary, Tamburlaine has no conscience and this defines him as, to borrow Nietzsche's concept in Thus Spoke Zarathustra (1883), the Superman.

Although autonomy is Tamburlaine's main objective, as asserted by the speech on fulfilment, "Nature, that framed us of four elements / Warring within our breasts for regiment / Doth teach us all to have aspiring minds" so eloquently affirms (1 Tamburlaine, 2.7.18-20), Tamburlaine's career is complicated by his capture of Zenocrate. He loves her at first sight, but as she does not reciprocate, being already betrothed, he postpones sexual possession until he conquers Damascus, home of her fiancé, in Act 5. In the meantime she is more his ward than his prisoner. In short, the love element in this Promethean figure is actually neoPlatonic. He sublimates it and thereby energises himself for military victory. In a way, Zenocrate's presence is superfluous, her role subdued into an ideal. Passive though she is, however, Zenocrate serves at key moments to reveal a softer element in Tamburlaine, thereby humanising him and retaining audience interest; otherwise, he would be a mere war machine. By her shocked reaction to the revenge code he characteristically displays with increasing violence she acts for the audience as a catalyst. He says at one point that Zenocrate's sorrows over his wilfulness "lay more siege unto my soul / Than all my army to Damascus' walls" (1 Tamburlaine, 5.1.155-56). Her compassion promotes a critique of Tamburlaine's inhumanity.

The cruelties Zenocrate witnesses and decries include the tortures of Tamburlaine's noblest prisoners Bajazeth, Emperor of Turkey, and his queen Zabina, to the point where, imprisoned and ill-treated in a cage, both run mad and spectacularly kill themselves. So far as Zenocrate is concerned this is beyond bearing, and her horror reaches the audience but not Tamburlaine, whose response is, "This is my mind, and I will have it so" (1 Tamburlaine, 4.2.91). What is the audience to think? This divided response must have been Marlowe's intention. It is an artistic manoeuvre akin to what today we call Brechtian alienation, “complex seeing," forcing an audience to step back, look again, and think. ${ }^{42} \mathrm{We}$ must, however, appreciate both Zenocrate's pity and Tamburlaine's warrior ethic. In effect, she is necessary to his sternness, the possibility of a wholeness which Marlowe never provides. Subsequently, Tamburlaine refuses Zenocrate's plea to show mercy to her home country, and orders his horsemen to run at the pleading virgins with spears: "on Damascus' walls" they hoist up "their slaughtered carcases" because the city would not surrender in his time (2

\footnotetext{
${ }^{41}$ See William Shakespeare, Hamlet, ed. G. R. Hibbard (Oxford: Oxford University Press, 1994), 3.4.167. Hamlet regrets that he must be punished as heaven's "scourge and minister."

${ }^{42}$ Bertolt Brecht, Brecht on Theatre, ed. and trans. John Willett (New York: Hill and Wang, 1964), 44.
} 
Tamburlaine, 5.1.130-31). His "will to power," his aspiration to omnipotence, makes him believe he controls time (a belief Faustus was also to deceive himself into). Zenocrate's death and his own in Part 2 expose the pathos of such self-deception.

It was Edward Alleyn's task to make Tamburlaine in some measure "admirable" (wondrous) to the groundlings: an outsider, one of those who defied the authorities in order to speak out for autonomy and who brought art/poetry to the common people. This, it seems, is the only valid explanation for the speech from Tamburlaine, "What is beauty, saith my sufferings, then?" (1 Tamburlaine, 5.1.160-70). He answers the question himself: "If all the pens that ever poets held / Had fed the feeling of their masters' thoughts / And every sweetness that inspired their hearts" and minds; and if all "the heavenly quintessence" poets distil from "their immortal flowers of poesy" to the point that "as in a mirror" we can perceive the highest reach of thought, the great poem would still be unfinished. Marlowe may have had Lyly's Campaspe in mind here. In a key scene Apelles the artist tells Alexander the Great, his rival in love, that he can't have the portrait of Campaspe because it isn't finished: "Never finish! For always, in absolute beauty, there is somewhat above art."43 By extension, all endeavour, all ambition must be limited. This gap between ideal and realisation speaks to Tamburlaine's sorrow and momentarily humanises him.

Just as the atrocities in Part 1 indicate the price of success, with Zenocrate as prize, in Part 2 Tamburlaine's relentless campaign reflects the hollowness of victory. The worst atrocity in Part 2 is probably the murder on stage of his son Calyphas for betraying the "fire of this martial flesh," meaning his own (2 Tamburlaine, 4.1.105). In killing his unwarlike son the Titan Tamburlaine is killing the feminine in himself; in inspiring his other sons to pattern themselves on him he is more alienating still. It is impossible to empathise with Tamburlaine after this point. This is where directors usually cut the battle scenes down and move on to Babylon for Tamburlaine's last siege. This creates a parallel with the siege of Damascus that ends Part 1 and lends unity to the two parts. Instead of the joys of victory and marriage which crown the end of Part 1, however, Tamburlaine's death scene ends Part 2 in his apotheosis.

The ending fulfils the overall aim of the two plays, namely to show forth machismo and ambivalent "honour" in striking contrast to the catastrophe which closes Dido, Queen of Carthage. Tamburlaine shows how a man dies well. He has no Macduff to defeat him in single combat, illustrating the conquest of good over evil; but he has uplifting words still in

\footnotetext{
${ }^{43}$ John Lyly, Campaspe, in Five Elizabethan Comedies, ed. A. K. Mcllwraith (London: Oxford University Press, 1934), 3.4.103-4, italics in original.
} 
glorification of the warrior caste. A contrast with Coriolanus would also reveal the uniqueness of Tamburlaine. He never weakens, even in the face of ultimacy. What he "mirrors" is the inescapability of endurance.

Imagery of fire reappears in the final Act, and an actual fire is lit on stage to burn the Koran and the "heaps of superstitious books / Found in the temples of that Mahomet / Whom I have thought a god" (2 Tamburlaine, 5.1.172-73). Modern editors, alarmed at the potential danger to the audience, helpfully suggest that "perhaps a metal container is used to shield the stage." 44 Shortly thereafter Tamburlaine suddenly falls fatally ill. It seems clear from the text that blasphemy must be seen, perhaps in fear of the official censor, as the cause of Tamburlaine's death. This would represent tragic retribution, but would it represent Marlowe's thinking? Mark Thornton Burnett sees confusion here over the "scourge of God" role, but adds: "Whatever reading is privileged in these closing stages, Tamburlaine is incapable of subverting his own destiny." 45 This returns us to Horace in Odes 2.18 and how the attendant of Orcus, who escorted dead souls to Hades, "could not be bribed with gold to untie Prometheus for all his cunning" (Odes 135). Marlowe, however, envisages no punishment after death; indeed, Tamburlaine's soul will pierce through Zenocrate's coffin and bring her "a heaven of joy" (2 Tamburlaine, 5.3.227), in which, presumably, he will share. Retribution does not apply.

Marlowe tries to answer Horace and to retain Tamburlaine's glory as ongoing. While insulting Muhammad, placing him in hell with lines that could not nowadays be spoken on any stage, Tamburlaine urges his men to "Seek out another godhead to adore, / The God that sits in heaven, if any god, / For he is God alone, and none but he" (2 Tamburlaine, 5.1.198200). This is obscure enough to pass as an endorsement of Christianity. Then the imagery of fire associated with Phaeton and linked to the stage chariot drawn by the two kings now becomes a warning as it is bequeathed to his son Amyras: he must master this chariot better than Phaeton his. It is implied that Tamburlaine has handled it to perfection.

When his father dies, five lines from the end of the play, Amyras strikes an apocalyptic note: "here let all things end! / For earth hath spent the pride of all her fruit, / And heaven consumed his choicest living fire" (2 Tamburlaine, 5.3.249-51). Prometheus is mourned as he passes on like Dido surrounded by fire and Tamburlaine is transformed into uneasy myth.

\footnotetext{
${ }^{44}$ Marlowe, Doctor Faustus and Other Plays, 430n176.

${ }^{45}$ Mark Thornton Burnett, 'Tamburlaine the Great, Parts One and Two', in The Cambridge Companion to Christopher Marlowe, ed. Patrick Cheney (Cambridge: Cambridge University Press, 2004), 139-41.
} 


\section{Bibliography}

Bacon, Francis. The Essays. Edited by John Pitcher. Harmondsworth: Penguin, 1985.

Baldick, Chris. The Concise Oxford Dictionary of Literary Terms. Oxford: Oxford University Press, 1991.

Brecht, Bertolt. Brecht on Theatre. Edited and translated by John Willett. New York: Hill and Wang, 1964.

Brooke, C. F. Tucker and Nathaniel Burton Paradise, eds. English Drama 1580-1642. Boston: Heath, 1933.

Brown, John Russell ed. Tamburlaine the Great, Edward the Second and The Jew of Malta: A Casebook. London: Macmillan, 1982.

Burnett, Mark Thornton. "Tamburlaine the Great, Parts One and Two." In The Cambridge Companion to Christopher Marlowe, edited by Patrick Cheney, 139-41. Cambridge: Cambridge University Press, 2004.

Cole, Douglas. Suffering and Evil in the Plays of Christopher Marlowe. Princeton: Princeton University Press, 1962.

Deats, Sara Munson. “"Errant Eros': Transgressions of Sex, Gender, and Desire in Dido,

Queene of Carthage." In Christopher Marlowe, edited by Robert A. Logan, 89-124.

Farnham: Ashgate, 2011.

Donoghue, Denis. Thieves of Fire. London: Faber, 1973.

Drayton, Michael. "To My Most Dearly Loved Friend Henry Reynolds, Esquire, of Poets and Poesie.” In Works, edited by J. William Hebel, 228-29. Oxford: Blackwell, 1961.

Duxfield, Andrew. Christopher Marlowe and the Failure to Unify. Farnham: Ashgate, 2015. Fehrenbach, Robert J., Lea Ann Boone, and Mario A. Di Cesare, eds. A Concordance to the Plays, Poems, and Translations of Christopher Marlowe. Ithaca, NY: Cornell University Press, 1982.

Greenblatt, Stephen. Renaissance Self-Fashioning: From More to Shakespeare. Chicago: University of Chicago Press, 1980; new edn. 2005.

Halliwell, Stephen. The Poetics of Aristotle: Translation and Commentary. Chapel Hill: University of North Carolina Press, and London: Duckworth, 1987.

Haydon, Liam. Stephen Greenblatt's Renaissance Self-Fashioning. London: Macat, 2018. Horace, Odes and Epodes, Loeb Classical Library. Edited and translated by Niall Ross.

Cambridge, MA: Harvard University Press, 2004.

Lunney, Ruth and Hugh Craig. "Who Wrote Dido, Queen of Carthage?" Journal of Marlowe Studies 1 (2020): 1-31. 
Lyly, John. Five Elizabethan Comedies. Edited by A. K. McIlwraith. London: Oxford University Press, 1934.

Marlowe, Christopher. Hero and Leander. In The Norton Anthology of English Literature, $5^{\text {th }}$ Edition, Vol. B, edited by Stephen Greenblatt, Katharine Eisaman Maus and George Logan, 660-78. New York: Norton, 2018.

Marlowe, Christopher. Dido Queen of Carthage and The Massacre at Paris. Edited by H. J. Oliver. London: Methuen, 1968.

Marlowe, Christopher and his Collaborators and Revisers. Doctor Faustus A- and B-texts (1604, 1616). Edited by David Bevington and Eric Rasmussen. Manchester: Manchester University Press, 1993.

Marlowe, Christopher. Doctor Faustus and Other Plays. Edited by David Bevington and Eric Rasmussen. Oxford: Oxford University Press, 1995.

Montaigne, Michel de. Essays. Translated by J. M. Cohen. Harmondsworth: Penguin, 1958.

Nagler, A. M. Shakespeare’s Stage. New Haven: Yale University Press, 1958.

Riggs, David. The World of Christopher Marlowe. London: Faber, 2004.

Sales, Roger. Christopher Marlowe. Basingstoke: Macmillan, 1991.

Shakespeare, William. Hamlet. Edited by G. R. Hibbard. Oxford: Oxford University Press, 1994.

Sidney, Sir Philip. A Defence of Poetry. Edited by Jan Van Dorsten. Oxford: Oxford University Press, 1973.

Virgil. The Aeneid. Translated by Robert Fagles. London: Penguin, 2006.

Virgil. Aeneid Book VI. Translated by Seamus Heaney. London: Faber, 2016.

Waith, Eugene M. The Herculean Hero in Marlowe, Chapman, Shakespeare and Dryden. New York: Columbia University Press and London: Chatto and Windus, 1962.

Wiggins, Martin. "When Did Marlowe Write Dido, Queen of Carthage?” Review of English Studies 59, no. 241 (2008): 521-41. 